https://doi.org/10.22364/ruslat.9.14

\title{
Ольга Проскурова-Тимофеева
}

\section{«Элементарное родиноведение»: тема родины в изданиях для детей и юношества рижского акционерного общества «Саламандра» в середине 1920-х годов}

В статье рассматривается разнообразие подходов рижского издательства «Саламандра» к теме родины при обращении к Аетской аудитории. Рижские изАатели принимали во внимание интересы и ценности различных аАресатов: юного покомения коренного (старожильческого) населения Аатвии; детей эмигрантов, недавно покинувших Россию и нашеАших приют в Аатвийской Республике; маленьких читателей в Аругих центрах русского зарубежья, гАе распространялись изАания из Риги. При формировании «Аетского текста» рижской прессы в рассматриваемый период особую роль играла обеспокоенность так называемой денационализацией нового поколения, охватившая интемектуальные круги русской эмиграции в середине 1920-х годов; на содержание также оказывали влияние мичные идеологические и аксиологические установки реАакторов изАаний Аля детей. В матвийских учебниках по родиноведению, издаваемых «Саламандрой», прослеживается растерянность составителей при отборе материала на тему родины.

Ключевые слова: детская периодика, детская пресса, межвоенная $\Lambda$ атвия, русская эмиграция, родина, родиноведение, «Саламандра».

В независимой Аатвии вплоть до середины 1920-х гг. серьезных попыток наладить профессиональный выпуск Аетских периодических изАаний на русском языке практически не предпринималось. Исключение - издатемьская инициатива жителей Аибавы (ныне Аиепаи). Прошение о выпуске русскоязычного журнала Аля Аетей было подано в матвийское Министерство внутренних Аел (MBA $\Lambda$ P) 14 октября 1921 гоАа: «Журнал преАпомагаем изАавать от оАного Ао Авух номеров в месяц. Цель изАания - Аать Аетям художественный материа Аля чтения. Журнац будет имлюстрирован рисунками. Название журнала “Божий мир”. Издатемями журнала будем мы, Гравит и Бурнашев - оба, а редактором я, Бурнашев» [1:440].

Отдел по делам прессы MBA $\Lambda$ Р потребовац от ответственных служб собрать сведения об Эрне Гравит и Михаиле Бурнашеве. Полиция выяснима, что Гравит - российская поААанная 25-ти мет, без определенного рода Аеятельности, замужем за вмаАельцем мибавской мыльной фабрики. Бурнашев - поААанный России, женат, учитель. В отчетах полиции сообщалось, что «неблагоприятных сведений» и «компрометирующей информации» о политической неблагонадежности будущих изАателей нет [1: 441-448]. В сопроводительной полицейской записке уточнялось, что задуманный 
журнал будет аАресован детям 6-12 мет. В нем планируется печатать «библейские стихи, сказочки и Аетские рассказики с имюстрациями и рисунками, только Аля детей» [1: 445]. Аокументы из фондов Аатвийского го-

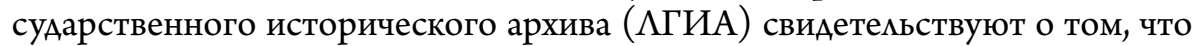
в начале ноября 1921 года разрешение на выпуск изАания было получено, однако достоверных данных, быц ми отпечатан хоть один номер «Божьего мира», пока не обнаружено ${ }^{1}$.

Михаил Николаевич Бурнашев (1882-1928) - одна их ключевых фигур в развитии русской детской периодики межвоенной $\Lambda$ атвии. Он родился 11 марта 1882 года в Курской губернии Российской империи, в семье потомственных Аворян. В упомянутых выше отчетах полиции говорится, что он прибыл в Аибаву в 1918 году. Поначалу давал частные уроки и работал демопроизводителем на «бывшей машинной фабрике Бёкера $\gg^{2}$ [1: 444-445]. В сентябре 1921 года Бурнашев покучил официальное разрешение матвийского Министерства образования на работу учителем, преподавал русский язык и историю в ряде мибавских шком [1: 445].

В 1925 году М. Н. Бурнашев был рукоположен в священники архиепископом Иоанном (Поммером). ОАновременно с выполнением своих обязанностей священноскужителя отец М. Бурнашев продолжал вести преподавательскую деятельность уже в Риге: учил детей в школе при Свято-Троицком Сергиевом женском монастыре, был законоучителем в рижской частной гимназии А. К. Корти [2].

КогАа в конце 1925 года акционерное общество печатного дема «СаламанАра», основанное в Риге российским эмигрантом, предприниматемем и меценатом Николаем Алексеевичем Белоцветовым (1863-1935), заявияо о намерении всерьез заняться изданием периодики Аля детей, о. Бурнашев стал одним из основных действующих миц этого направления деятельности изАательства.

В ноябре 1925 года «СаламанАра» приступияа к изАанию «ежедневной русской национально-демократической» газеты «САово» - потенциального конкурента рижской газете «СегоАня». Абрис своей программы реАакция «Слова» очертила в пятом номере:

Мы считаем самостоятельное существование Иатвии благом Аля нас, которым мы не можем не дорожить и которого мы не можем не защищать. Һатвия аля нас, русских, не только приют (курсив мой - О. П.-Т.), но и государство, поА кровом законов

1 Автор статьи благодарит матвийского исследователя Б. А. Равдина за рекомендацию обратить внимание на эти архивные документы.

2 «Фабрика Бёкера» имеет давнюю историю. В 1882 году владелец вестфальского метамлургического предприятия Вимьгельм Бёкер построим в Аибаве завоА Аля производства проволочного железа, проволоки и гвоздей. РуковоАство преАприятием взял на себя его сын - ААольф Бёкер. В советское время завод был известен поА названием «Sarkanais Metalurgs» («Красный метамург»), позже - «Liepājas

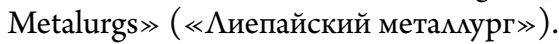


которого живут и развиваются матвийские гражАане русской национальности. Но само собою разумеется, что мы горячо желаем восстановления России, - не той, конечно, России, гАе террор и насилие возведены в систему управления, а правовой, Аемократической, свободной России, которая была бы построена на началах социальной справеАливости и национального равенства [3: 116].

Почти одновременно с запуском газеты «Слово» акщионерное общество «Саламандра» начало издавать еженедельный митературно-художественный, богато имлюстрированный журнал «Перезвоны». Он намеревался конкурировать с подобными себе изданиями на более широком рынке - русского зарубежья. Раздел журнала «Перезвоны» - «Аетский уголок» - стал первым поАступом «СаламанАры» к Аетской аудитории в периодической печати. Его реАактором и был назначен о. Бурнашев. По свеАениям Ю. И. Абызова, «ближайшее участие принимах Иван Аукаш» [3: 91].

С ноября 1925 года по май 1926 года разАел «Аетский уголок» публиковался в каждом номере «Перезвонов» (№№ 1-18). Ему отводились последние страницы журнала, которые отделялись от остального содержания номера специальным графическим оформлением. Количество страниц равнялось 4 в первых пяти номерах и выросло до 6 в Аальнейшем. САвоенный «святочный выпуск» 1925 года занял 12 страниц. Этот разАел «Перезвонов» изАавался, как и сам журнац, по правилам старой орфографии и имел сквозную пагинацию.

В «Аетском уголке» не соблюАалась строгая рубрикация, оАнако достаточно рано были сформированы читательские ожиАания: чаще всего разАел преАставлял собой подборку русских быцин, сказок, стихов (А. С. Пушкина, Н. А. Некрасова, А. Н. Майкова, И. 3. Сурикова, А. Н. Кайгородова и Ар.) и рассказов $\Lambda$. Н. Толстого. СреАи наиболее объемных перепечаток классики - «Песнь о вещем Олеге» и «Сказка о рыбаке и рыбке» А. С. Пушкина, «Ночь накануне Рождества» Н. В. Гоголя, «Мамьчик у Христа на елке» Ф. М. Аостоевского, «На Страстной неАеле» А. П. Чехова.

Особое место в «Аетском уголке» принадлежало «Фейным сказкам» К. А. Бальмонта. Он - самый частотный «новый» автор, преАставленный в разделе. Из Аругих, современных журналу авторов, в «Аетском уголке» печатались И. А. Бунин, В. Ф. Ходасевич, А. Н. Толстой, И. Ф. Наживин.

В трех последних номерах были опубликованы метописные сказания в изложении самого о. Бурнашева поА общим названием «Из родной старины». В номере № 18 детский раздел закрывался стихотворением рижского поэта Виктора Третьякова «ПоцАень», которое также изобиловало отсылками к Аревнерусской истории.

В апреле 1926 года МВА АР получимо прошение о выпуске «Аетского уголка» отАельным изАанием: «Акционерное общество печатного Аела "Саламандра" <..> просит разрешения изАавать Аетский раздел журнала "Перезвоны" в виде отдельного журнала Ава раза в месяц под названием “Аетский уголок” и назначить ответственным редактором бывшего 
российского подАанного о. Михаила Николаевича Бурнашева <...> [4:

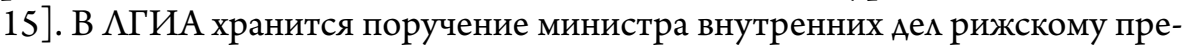
фекту снова собрать Аополнительную информацию об о. Бурнашеве. По итогу проверок, ответственные инстанции рапортоваци, что компрометирующие сведения не обнаружены, и препятствий Аля выпуска нового изАания нет [4: 16-24].

В мае и начале июня 1926 года вышио три номера «Аетского уголка» с пометой на обложке «Беспиатное приложение к журналу “Перезвоны”. В отдельной продаже 16 сант. (8 руб.) $\gg$. На восьми его страницах - Н. В. Гоголь, А. Н. Плещеев, $\Lambda$. Н. Толстой, В. П. Авенариус; очерки о первых русских путешественниках и книгопечатниках; игры и шарады. После выхода третьего номера в июне 1926 года изАание прекратило свое существование.

В силу общей ценностной ориентации фмагманских изАаний «Самамандры» (газеты «С ово» и журнала «Перезвоны») тематической Аоминантой «Аетского уголка» поА реАакцией о. Бурнашева стала Россия - ее история, рекигия, культура. Подбор материалов аля раздела основывался на траАиционных преАставлениях о произвеАениях русской митературы, предназначенных Аля Аетей и призванных сохранить и укрепить их принаАлежность к русской национальной кумьтуре. Тема России, тема родины - важнейшие Аля рижского «Аетского уголка», ориентированного, прежАе всего, на общую Аетскую аудиторию русского зарубежья. При их разработке реАакция планомерно придерживалась еАинственного вектора - «родина - Россия $»^{3}$.

3 Весной 1926 года в изАательстве «Саламандра» поА редакцией о. Бурнашева также вышел объемный имлюстрированный сборник (88 страниц большого формата) А^я Аетей и юношества поА названием «Родина». ИзАание открывалось следующим обращением к читателям: «ВАали от родины, на чужбине, растут, воспитываются и получают свое Ауховное развитие наши дети. Все чаще и чаще можно слышать голоса о денационализации подрастающего покомения. Сборник "Родина" ставит себе задачей помочь родителям и школе в этом больном и опасном своими последствиями вопросе. $<\ldots>$ Подвижники русской церкви и национальные богатыри и герои, царственный своим величием ПетрограА и сказочная своей архитектурной фантастикой и седой стариной Москва, тихий провинциальный гороА и беАная русская Аеревушка с церковкой на погосте, Аремучий мес и поле - все это нашло себе место в нашем сборнике» [5: 3]. Сборник продолжал и развивац Аоминантную тематику «Аетского уголка». Его содержание отражало общее настроение эмигрантских кругов в центрах русского зарубежья тех мет. Книгу поА реАакцией о. Бурнашева не оставила незамеченным рижская газета «Сегодня». Известный критик Юлий Айхенвальд отмечал: «В сборнике даны: образцы народных былин, исторических песен, “САово о полку Игореве”, воззвания Аионисия, народные сказки, наиболее проникнутые национальной стихией отрывки из Пушкина, Аермонтова, Толстого, Гоголя, Тургенева, Кольцова, Никитина, Некрасова. Из историков даны отрывки из Карамзина и КАючевского. В сборнике несколько хороших репродукций в красках и много снимков с картин, рисующих русскую природу, русскую историю и русский быт. Стремясь Аать самое бесспорное и несомненное из русской китературы, сборник приближается к хрестоматии. По нашему мнению, хрестоматический 
Своеобразную альтернативную редакционную минию внутри «Самамандры» по отношению к Аетским изАаниям, нахоАившимся в веАении о. Бурнашева, выстраивац преАставленный издательским Аомом в конце 1925 года новый журнал Аля семьи и юношества «Юный читатель».

27 ноября 1925 года на имя министра внутренних дем Аатвии было поАано прошение: «Желая с 15-го сего Аекабря изАавать на русском языке журнал Аля детей среАнего возраста поА названием “Юный читатель”, просим выдать соответствующее разрешение. Журнац будет выходить Ава раза в месяц (1 и 15 числа) и печататься в типографии “Саламандра” - Б. Кузнечная, 43. Ответственный реАактор - матвийская подАанная Елена Николаевна Андрусова - 26 мет, жив<ет> в Риге по Ганзейской ум. А. № 2а кв. № 3, УАовметворяет всем требованиям ст. 2 и Аругих Закона о печати» [7: 571]. На оборотной стороне Аокумента - подпись Аочери главы «Саламандры» Н. А. Белоцветова: «Принять на себя ответственное редактирование журнала “Юный читатель” согласна. УАовметворяю требованиям Закона о печати /ст. 2 и Ар./: матвийское подАанство, бмагонадежность, возраст. <...> Елена Андрусова» [7: там же]. 30 ноября 1925 года издание детского журнама бымо официально одобрено МВА $\Lambda$ Р [7: 572].

Спустя Аень реАакция газеты «Слово» опубликовала материал в жанре «анкета», в котором интересовацась, каким, по мнению опрашиваемых, Аолжен быть Аетский журнал: «В связи с новым кумьтурным начинанием издательства "Сацамандра" - изданием журнала для семьи и юношества “Юный читатемь", мы обратились к выдающимся преАставителям педагогики, искусства, митературы и публицистики с <этим > вопросом» [8].

Известные рижские интемлектуалы дали развернутые ответы: в них, как правило, высказывалась належда на сохранение чистоты русского языка у молодого читателя, живущего за предеками России, а также желание видеть на страницах Аетского изАания больше материалов о русской культуре и искусстве ${ }^{4}$.

РеАакция также собрала ответы на вопрос анкеты у преАставителей главной аудитории журнама - Аетей -, пообещав серьезно отнестись к их мнению. Маменькие читатели признавались, что ожилают, в основном, публикаций прикмюченческой и экзотической направленности.

материал в общем доступен русским детям даже в эмиграции и было бы целесообразнее остановиться на Аругом» [6]. В 1927 гоАу о. Бурнашев выпустил в изАательстве «Саламандра» еще один сборник Аля детей - «Русь». ИзАание вновь преАставцяло собой антологию известных текстов (среди авторов - Н. М. Карамзин, В. О. КАючевский, С. М. Соловьев и Ар.). В сборнике также были опубликованы очерки самого о. Бурнашева об истории Киева, Москвы и Санкт-Петербурга, часть из которых ранее печаталась на страницах «Аетского уголка».

4 Среди опрошенных - депутат Сейма Аатвии, видный общественный деятель Е. М. Тихоницкий, известный педагог Ф. А. Эрн, художник Н. П. БогАанов-Бельский, писатель И. С. Аукаш, журналист Г. И. Гроссен (псевдоним Нео-Симьвестр). 
Назначенный на Аолжность редактора «Юного читателя» $\Lambda$. Кормчий подытоживац анкету: «Я искренне раА, что взгляды, высказанные г. г. пеАагогами, преАставителями искусства и митературы, а равно и пожелания моих будущих читателей совпаАают с моими преАставлениями о журнале Аля юношества. Приложу все усилия, чтобы “Юный читатель” под моим руководством стал не только приятным развцечением, но и светочем Аля юных Ауш» $[8]^{5}$. Примечательно, что в Аичной переписке реАактор $\Lambda$. Кормчий, помещенный, по выражению Ю. И. Абызова, «поА наАзор» Андрусовой, преАставительницы семейного кмана Белоцветовых, называц «Юный читатель» «моим журналом» 6 .

В течение года с небольшим - с середины декабря 1925 года по конец Аекабря 1926 года - новое детское изАание «Саламандры» исправно выхоАило Аважды в месяц. Количество страниц в Авадцати пяти номерах варьировалось: от 50 в первые месяцы издания, когАа на номер приходилось Ао 6 страниц рекламы, до 30-32 - на исходе существования журнала. КажАые шесть номеров 1926 года имели сквозную пагинацию. Журнал печатался по правилам старой орфографии. Оригинальные имлюстрации выполнялись хуАожниками Николаем Пузыревским (автор обложки) и Генрихом Аайбером.

«Юный читатель» был относительно строго структурирован. Обычно номер открывался несколькими приключенческими рассказами русских или зарубежных авторов. Вторую половину номера занимали постоянные рубрики, напр., «Бой-скаут», «Юный филателист», «Фотограф-любитель», «Радио», отражавшие интересы и увлечения современных журналу читателей-детей. Регулярные разделы «Обо всем понемногу», «По белу свету» содержали заметки об интересных происшествиях, служили «маменькими энциклопедиями» мюбопытных фактов. Традиционными были также разделы «Спортивный уголок», юмористические страницы, загаАки и конкурсы.

Отдельное внимание на страницах «Юного читателя», как того ожиАали взрослые участники анкеты «Слова», уделялось теме России и русской культуры. В первой половине 1926 гоАа регулярными были рубрики

$5 \Lambda$. Кормчий - один из писательских псевдонимов Аеонарда Юлиановича Коромя-Пурашевича (1876-1944). Эти официальные персональные данные хранятся в Регистре паспортов жителей Аатвии (1918-1940). Подлинная фамилия трудно установима $[9,10 ; 11]$. В разные времена он выступац в печати поА псевдонимами $\Lambda$. ГАанский, $\Lambda$. Королев, Мих. Катков, Петров-Суворов, Эмь-Ка, $\Lambda$. Кошевой, ека, граф $\Lambda$ ео Нарт, граф еон ГарА, П. Чунчин и Аругими: «речь в Аанном случае идет не только о митературной игре, но о множестве “мичностей”, “профилей” [10:23]. Фигура Короля-Пурашевича вызывала неоднозначную реакцию в журналистских и митературных кругах Риги.

6 Ср. письмо $\Lambda$. Кормчего Александру Аехтереву: «Я напечатал Ваши стихи в "Юном Читателе”. Желая Вас видеть постоянным сотрудником моего журнала (курсив мой - О. П.-Т.), позволия себе поместить Ваше имя в числе сотрудников. Надеюсь, не будете протестовать?» [12]. 
«Были и сказания Руси» и «Беседы по истории русского искусства»; в каждом номере рассказывалось об одном из преАставителей русской классической митературы - публиковались очерки о жизни А. С. Пушкина, М. Ю. Аермонтова, А. С. Грибоедова, $\Lambda$. Н. Толстого, И. С. Тургенева.

Примечательны бемлетризованные воспоминания ответственного реАактора журнала Е. Н. АнАрусовой - «Святки в Белом Теремке» (святочный №, 1925) и «Как я Теремок продавала. Страничка из прошиого» (№ 6, 1926), экспмуатировавшие мотив ностальгии по России, «утешительный миф», о необходимости которого чуть позже писал А. В. Амфитеатров в своей программной статье «К русскому обществу» (1928): «Аайте же русским детям хоть какую-нибудь реализацию утешительного мифа» $[13: 324]^{7}$.

Тем не менее, с завидным постоянством на страницах журнала появця-

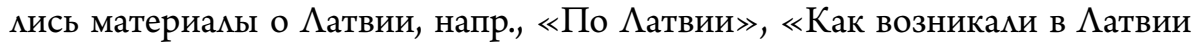
города», «Руины Вендена ${ }^{8}$. Журнал изобимовал матвийскими мокусами и в той его части, гАе печатались заметки об актуальных событиях, к примеру, сообщения о магере бой-скаутов поА Ригой или фотографический очерк о Аетском отдыхе в санатории на рижском взморье. В декорациях режицкого замка происходило действие рассказа $\Lambda$. Кормчего «За Аревним кладом» $(№ 5,1926)^{9}$. Аокальные фольклорные мотивы также обыгрывалась им в цегенде «Царь-рыба. Из мегенА Прибалтики» (№ 1, 1926).

Аюбопытны отдельные формулировки в публикациях о Аатвии. Юному читателю преАлагалось познакомиться с «историческими Аревностями и красотами природы родной страны (курсив мой - О. П.-Т.)» [16]. Принимая во внимание агитационную природу взглядов Кормчего на детское чтение $^{10}$, можно преАположить, что реАакция «Юного читатемя» преАпринимала осознанную попытку множественной аАресации. Сложный разговор о родине журнал вел сразу с несколькими целевыми аудиториями: одной частью своих материалов он укреплял принадлежность к $\Lambda$ атвии у юного

7 Подобный тип бемметристики Аля Аетей бым не редок в митературе русской эмиграции 1920-х годов. Ср. отклик в рижской прессе на книгу В. Нарышкиной-Витте «Записки девочки» (Берлин, 1922): «Авторша - дочь С. Ю. Витте - желает поАелиться со своими Аетьми воспоминаниями детства» [14] или отзыв на книгу Е. Ильиной-Полторацкой «Как мы жими в старинной усадьбе» (Берлин, 1923): «Он <рассказ> рисует жизнь в старинной русской Аворянской усадьбе, как она преАставлялась восьмилетней девочке или, вернее, как она запечатлелась в детских воспоминаниях автора, и переносит юных читателей в недавнее, но уже Аалекое прошиое $>[15]$.

8 Предположительно, это были отрывки из книги $\Lambda$. Кормчего «Наша родина. Очерки по географии Аатвии» (тип. Р. А. Зальпиуса, 1923) - редкого изАания, отсутствующего в матвийских библиотеках. ВыАвинутое преАположение на Аанный момент не явмяется верифицируемым.

9 В Режице (сейчас Резекне) Король-Пурашевич, по-видимому, провел свои первые годы жизни в $\Lambda$ атвии, преподаваА в местной гимназии.

10 Об этом свидетельствуют программные статьи $\Lambda$. Кормчего - поначаку в советской газете «ПравАа» $[10: 20]$, позже в рижских изданиях $[17,18]$. 
поколения коренного (старожильческого) русского населения и сближал с новой «роАной страной» ребенка-эмигранта. Аругая часть публикаций подАерживала культурно-историческую связь с Россией - как у перечисменных читательских групп, так и у аудитории в Аругих центрах русского зарубежья ${ }^{11}$.

В июне 1926 года, вслеА за «Воззванием русских писателей, ученых, артистов и художников», подписанным месяцем ранее в Париже ${ }^{12}$, «Юный читатель» наметил смещение акцентов в своей редакционной политике: «В журнале обращено особое внимание на борьбу с денационализацией русского юношества и на воспитание его в духе русской кумьтуры. Особый отАел “Были и сказания Руси” посвящен истории России и ее славному прошиому. “Юный читатель” необходим каждой семье, заботящейся о сохранении в Аушах Аетей культурной связи с Россией» [19].

ОАнако провозглашенные «поправки» носили, скорее, Аекларативный характер: материалы о Аатвии продолжали публиковаться в последующих номерах журнала (напр., «Певческие празАники Аатвии» (№ 13, 1926), «Зеленая Аева Аондангенского замка. Из матвийской старины» (№14, 1926), а рубрика «Быми и сказания Руси», напротив, практически исчезма, мелькнув Аишь однажАы в ноябрьском номере (№ 21, 1926).

Во второй половине 1926 года со страниц журнала пропал и раздел «БесеАЫ по истории русского искусства» поА реАакцией профессора Н. И. Мишеева. О прошлом России юным читателям напоминали редкие очерки о жизни русских писателей, а также повесть «Ермак» В. РаАича (№ 16-18, 1926) - преАположительно, перепечатка из Аореволюционного журнала «Всходы», который некогАа реАактировац $\Lambda$. Кормчий. Тема родины затмевалась Аругой тематической составмяющей «Юного читатемя» - материалами приключенческой и экзотической направленности ${ }^{13}$.

11 О широкой географии подписчиков журнала свидетельствуют рубрики «Почтовый ящик», «Юный филателист», ответы на конкурсные задачи: письма в реАакцию приходили из Ковно (сейчас Каунас), Ревеля (сейчас Тамлин), Юрьева (сейчас Тарту), Гельсингфорса (сейчас Хельсинки), Белграда, Софии, Берлина.

12 В начале мая 1926 года в Париже было подписано «Воззвание русских писателей, ученых, артистов и художников», в котором была выражена сильная обеспокоенность Аенационализацией молодого поколения русских эмигрантов. СреАи подписавших воззвание были многие известные писатели русского зарубежья.

13 На этом фоне интерес представляют Ава сочинения молодого рижского автора «Юного читателя» ВАадимира Эшенбруха. Его первый рассказ «Гришка-пономаренок» был опубликован во втором номере «Юного читателя» за 1926 гоА. В нем - единожды на страницах журнала - затрагивалась знаковая аля прозы русской эмиграции «первой волны» тема границы с Советской Россией. По сюжету рассказа, сирота Гриша, сын покойного пономаря, живет в Аеревне на советско-эстонской границе. Та часть села, где находится церковь, отошиа к СССР. Гриша тайно прибирает храм и чистит иконы, подвергая свою жизнь опасности. Чудом спасшись от большевиков, пономаренок перебегает границу и оказывается в Эстонии, гАе его усыновцяет семья священника. Сам ВАадимир Валентинович 
Показательно, что этот журнац издательства «Саламандра» учитывац гетерогенность своей читательской аудитории и разрабатывац разновекторный подхоА к теме родины, вкАючающий как направление «родина Россия», так и вектор «родина - Аатвия». Такую реАакционную политику журнала можно определить как более вариативную по сравнению с национально-консервативной стратегией ориентированного на широкую аудиторию русского зарубежья «Аетского уголка», но в целом не противоречившую установке, обозначенной в первых номерах газеты «Слово»ведущего периодического издания «Саламандры».

По-видимому, реАакционная политика «Юного читателя» отчасти была основана на мичных убежАениях $\Lambda$. Кормчего того времени, что поАтвержАается содержанием журнала «Новый читатель», который был созАан им еАинолично - сразу после закрытия «Юного читателя» в декабре 1926 года по причине финансовых затруднений изАательства ${ }^{14}$.

Примечательно, что в эти же годы «Саламандра» выпустила серию учебников аля русской школы ${ }^{15}$. Среди них - «Настольная хрестоматия

Шпис-Эшенбрух родился в Нарве в 1906 году в семье владельца ивангородской фабрики, прошел через многие жизненные испытания и нашел пристанище в $А$ атвии. «Гришка-пономаренок» быи одним из его первых писательских опытов. Читатель узнац об этом из некролога, посвященного Эшенбруху и опубликованного в пятом номере «Юного читателя». Молодой рижский автор скоропостижно скончался, а редакция дала обещание посмертно напечатать его второй рассказ в ближайших выпусках журнала. Рассказ «Мое Аетство и юность. Быль, рассказанная старым котом Васькой» быц опубликован в № 8, 1926 и преАставцял собой своеобразную версию «утешительного мифа».

14 Структурой и содержанием начинание $\Lambda$. Кормчего «Новый читатель» (вышло всего Ава номера в начале 1927 года) фактически копировало преАшественника. ГАавный текст обоих выпусков - новый приключенческий роман самого главного реАактора - «Исчезнувший остров». В нем $\Lambda$. Кормчий продолжил реализовывать стратегию разновекторного разговора с читателем о родине. Аействие романа начиналось в Риге - «новой родине» юных эмигрантов-сирот брата и сестры Марка и Аюдмилы. Начало романа изобиловало рижскими мокусами: «Марк мрачно сунул щетки в ящик, собрал несложный набор банок с сапожным кремом и захлопнул крышку: зачастил мелкий нудный дожАик, и на заработки приходимось махнуть рукой. Мутный осенний вечер затягивал тяжелой сизью Ригу. Вспыхивали огни в витринах магазинов напротив - на Елизаветниской ум., и от них серебристые блики можились на скользкие тротуары и мостовую» [20]. Встреченный на улице «странный незнакомец» напомнил Марку о его прошиом - детстве в России, тем самым иннервировав вектор «родина - Россия». Вероятно, название романа «Исчезнувший остров» - также символизировало потерянную главными героями родину. ОАнако, по причине незавершенности текста, это преАположение труАно ПодтверАИть.

15 В середине 1920-х гг. «Саламандра», подАерживая идею необходимости Аоступной по цене русской книги, издает в серии «Аешевая библиотека» «Капитанскую Аочку» А. С. Пушкина, «Вечера на хуторе близ Аиканьки» и «Тараса Бульбу» 
школьника с элементарными сведениями по родиноведению» ${ }^{16}$ рижского педагога Н. В. Кузнецова. Целевая аудитория учебника - внутрилатвийская. Географический раздел «элементарного родиновеАения» содержал исключительно матвийскую топонимику (реки и озера Аатвии, Рижский залив и пр.), общественно-политический - сведения по истории и государственном устройстве Аатвийской Республики (Сейм Аатвии, Президент Аатвии и пр.). Учебник бым выполнен в соответствии с правилами новой русской орфографии.

Аюбопытен параграф учебника под заголовком «Отечество», обозначивший опреАеленную растерянность составителя при описании базовых понятий «роАиновеАения»:

КажАый народ имеет свое отечество, свою родину. Отечеством называют страну, в которой мюАи роАились, провели Аетство, молоАость и в которой испокон века жили их отцы, деАы и прадеАы. Свое отечество АюАи называют роАиной. РоАиной они зовут потому, что в ней они роАились, Усвоили РОАной язык, в ней же похоронены на кладбищах их отцы, Аеды и прадеды и в ней же живут все их родные, Арузья и знакомые; нередко родину называют матерью < ... > На свете имеется много разных государств и очень богато устроенных, но у кажАого человека одна родная мать, одна у него и родина [21: 93-94].

В митературной части учебника приводимись хрестоматийные стихи о родине русских поэтов А. Н. Пиещеева, Ф. Н. Берга и М. Ю. Аермонтова. Отдельно стоит отметить, что стихотворение Аермонтова с известным зачином « Һюблю отчизну я, но странною мюбовью!..» было переписано и сокращено автором матвийского учебника. За это, в числе прочего, Кузнецова критиковац режицкий (резекненский) пеАагогический журнац «РоАная школа»: « Аермонтовская “Отчизна" начинается нелермонтовским

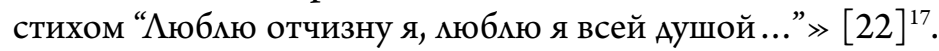

Н. В. Гоголя, также входящих в школьный канон русской митературы в межвоенной Аатвии.

16 В пеАагогической традиции Российской империи родиноведение, скорее, подразумевало географическую (пространственную) составмяющую изучения родного края; его семантика не включала идеологический и исторический аспекты.

17 Цитируемый номер общественно-педагогического журнала «Родная школа» (№ 1, 1930), выпускавшегося в Режице (ныне Резекне) Союзом русских учительских организаций в Аатвии, в основном, посвящен методологии преподавания родиноведения в русских школах Аатвии. В нем анализируются подходы к содержанию этого предмета, рецензируются выходившие в Аатвии учебники по родиноведению. 
Амя сравнения (исправления и сокращения отмечены курсивом - О. П.-Т.):

$\Lambda$ ермонтов:

Аюблю отчизну я, но странною любовью!

Не победит ее рассудок мой.

Ни слава, купленная кровью,

Ни полный гордого доверия покой,

Ни темной старины заветные преданья

Не шевелят во мне отрадного мечтанья,

Но я нюблю - за что, не знаю сам -

Ее степей холодное молчанье,

Ее месов безбрежнықх колыханье,

Разиивы рек ее, подобные морям <...>

[23: 509].
Кузнецов:

Аюблю отчизну я, люблю я всей душой, ее полей холодное молчанье, ее кесов дремучих колыханье, Размивы рек ее весеннею порой [21:128].

Учебник Кузнецова выявмял авторскую «креативность» при формумировке ключевых понятий в разговоре о родине с Аетской аудиторией межвоенной $\Lambda$ атвии. В то же время, этот вопрос не преАставцялся противоречивым Аля «Аетского уголка», раздела и приложения журнала «Перезвоны»: его издательские амбиции выходили далеко за пределы Аатвии, изАание не ограничивалось местной аАресацией. РеАактор «Аетского уголка» о. М. Бурнашев последовательно реализовывал развитие единственного тематического вектора «родина - Россия» и в Аругих вверенных ему изАаниях «Саламандры». Журнал «Юный читатель» поА реАакцией $\Lambda$. Кормчего пытался осуществцять разновекторную коммуникацию на тему родины, включавшую направление «родина - Аатвия». Таким образом, рижское акционерное общество печатного дела «Саламандра» Аемонстрировало множественность поАходов к теме родины при обращении к поколению русских Аетей, оказавшихся в новой исторической ситуации.

\section{Литература}

1. АГИА ф. 3724, оп. 1, еА. хр. 80.

2. О. Пухмяк, Покровское кмадбище. Слава и забвение, 2004. Аоступен на https:// www.russkije.lv/ru/pub/read/pokrovskoe-cemetry/svjaschenniki-3.html

3. Ю. Абызов, А издавалось это в Риге. 1918-1940: историко-библиографический очерк. М.: Библиотека-фонА «Русское зарубежье», Русский путь, 2006.

4. АГИА ф. 3724, оп. 1, еА. хр. 96.

5. М. Бурнашев (реА.), Родина. Рига: Саламандра, 1926.

6. Ю. АйхенвальА, «Родина», Сегодня, № 116. С. 8, 1926. 
7. АГИА ф. 3724, оп. 1, еА. хр. 92.

8. [Б. п.], «Каким должен быть “Юный читатель”?», Слово, № 17. С. 2, 1925.

9. Ср. Ю. Абызов, Р. Тименчик, «История оАной мистификации: Факты и гипотезы», Ааугава, № 9. С. 108-116, 1990.

10. Ср. Б. Хемлман, «Аетская митература как оружие: творческий путь $\Lambda$. Кормчего», в «Убить Чарскую...»: парадоксы советской митературы для детей (1920-1930-е гг.), сборник статей (сост. М. Балина и В. Вьюгин). С.-Пбг: Алетейя. С. 20-45, 2013.

11. Ср. Ж. Бадин, «Преступиение и наказание в творчестве $\Lambda$. Ю. Коромя-Пурашевича», Kultūras studijas XII. Noziegums un sods literatūrā un kultūrā (глав. реА. А. Сташукане. С. 37-50, 2020.

12. А. Король-Пурашевич, Письма Александру Аехтереву, 1926. Аоступен на http:// www.russianresources.lt/archive/Korm/Korm_3.html\#1

13. См. И. Арзамасцева, С. Николаева, Аетская митература. М.: ИзАательский центр «Академия», 2005.

14. [Б. п.], «В. Нарышкина-Витте. Записки девочки», Сегодня, № 76. С. 4, 1922.

15. Н. Н., «Е. Ильина-Полторацкая. "Как мы жили в старинной усадьбе”», Сегодня, № 27. C. 5, 1923.

16. Г. Я., «По Аатвии», Юный читатель, святочный №. С. 34, 1925.

17. $\Lambda$. К., «О Аетской книге», Наше будущее. С. 7, 1922.

18. $\Lambda$. Кормчий, «Зремища и Аети», Вечернее время, № 474. С. 4, 1925.

19. [Б. п.], [Без названия], Юный читатель, № 12. С. 95, 1926.

20. А. Кормчий, «Исчезнувший остров», Новый читатель, № 1. С. 3, 1927.

21. Н. Кузнецов, Настольная хрестоматия школьника с элементарными сведениями по родиноведению, часть II. Рига: Сацамандра, [1925].

22. А. Ф., «О книге и из книги», Родная школа, № 1. С. $30,1930$.

23. М. Ю. Аермонтов, «Родина», собрание сочинений в 4 т., т. 1. Москва, АенинграА: ИзАательство АН СССР, 1961.

\section{"Elementārā dzimtenes mācība": dzimtenes tēma Rīgas akcionāru biedrības "Salamandra" 1920. gadu vidū izdotajā bērnu un jauniešu literatūrā}

Rakstā aplūkota Rīgas izdevniecības "Salamandra” dažādās pieejas dzimtenes tēmas atspoguļojumam bērnu literatūrā. Rīgas izdevēji savā darbībā n̦ēma vērā dažādu izdevuma adresātu intereses un vērtības, jo "Salamandras" lasītāju loks bija raibs - tie bija Latvijas krievu tautības pamatiedzivotāju jaunatne; emigrantu bērni, kuri nesen bija pametuši Krieviju un atraduši patversmi Latvijas Republikā; mazie lasītāji citos krievu emigrācijas centros, kuros tika izplatīti Rīgas izdevumi. Veidojot Rīgas preses "bērnu tekstu”, īpaša nozīme tika pievērsta tā saucamajai jaunās paaudzes denacionalizācijas problēmai, kas 20. gadu vidū aptvēra krievu emigrācijas intelektuālo loku. Izdevumu bērnu literatūras saturu ietekmēja arī redaktoru personiskie ideologiskie un aksiologiskie uzstādījumi. Materiālu par dzimtenes tēmu atlasē Latvijas "Salamandras" izdotajās mācību grāmatās vērojams to sastādītāju mulsums. 


\section{"Elementary Homeland Studies": The Topic of Homeland in Publications for Children and Youth by Riga Publishing House "Salamandra" in the mid 1920s}

The article examines how the Riga-based émigré publishing house "Salamandra" approached a controversial topic of homeland when addressing its younger readers. In mid 1920s a complex message about homeland was communicated by the émigré publisher to its heterogeneous readership of Russophone children living in interwar Latvia. The message was multi-layered in attempt to target a young generation of a so called Latvian Russophone oldsettlers' community, children-emigrants whose families have left Russia recently and settled in a newly proclaimed Latvian Republic, and young readers in other Russian émigré centres where periodicals from Riga were distributed. Exploring publications for children and youth produced in Russian in interwar Riga, foregrounded the ambiguity of narratives about homeland. The editorial practices faced even greater complexity when historical, social and cultural backgrounds of younger readers intersected with the concerns of denatsionalizatsiya (denationalization) of a new émigré generation that embraced broader Russian emigration circles in mid 1920s. 